\title{
Civil Society Participation in Brazilian Foreign Policy: an Analysis of its Democratic Quality
}

\section{Melissa Pomeroy*}

\begin{abstract}
Working from an analytical framework that emphasises the horizontalisation of the decision-making process of Brazilian foreign policy, considered as public policy and subject to democratic control, this article analyses the democratic quality of this policy's participatory institutions, using the criteria established by democratic theory. Civil society participation is analysed in three areas of foreign policy: multilateral international negotiations, regional integration, and SouthSouth development co-operation. It can be stated that civil society participation in Brazilian foreign policy is of a diffuse nature, discretionary, and with a high degree of informality.
\end{abstract}

Keywords: Participation; Brazilian Foreign Policy; Civil Society; Democratic Quality; Foreign Policy Analysis.

\section{Introduction}

The Brazilian processes of democratisation and the economic opening of the last three decades favoured a diversification of foreign policy agendas. On the one hand, the commercial opening and the international insertion into a globalised economy, via a model of competitive integration of the productive chains, meant that foreign policy generated internal redistributive impacts, less pronounced in an economy of industrial protection (Lima 2000). On the other hand, political re-democratisation promoted an oxygenation in foreign policy, with the entry of new specialised actors - mainly governmental - to fulfil its new agendas and competencies (Pinheiro and Milani 2011). Among the main consequences of this broadening of foreign policy agendas are the administrative reforms in the Ministry of Foreign Affairs (Ministério das Relações Exteriores - MRE) and the increased demand for participation from social sectors in the processes of policy formulation and implementation (Milani 2011).

At the same time, in the domestic realm Brazil has undergone important transformations in terms of its democratic consolidation. On the one hand, it has experienced an

\footnotetext{
Articulação SUL, São Paulo-SP, Brazil: melissapomeroy@gmail.com.
} 
important phase of institutional innovation in the last twenty years, with the large-scale institutionalisation of participatory spaces giving shape to an unprecedented participatory context. On the other hand, Brazilian civil society has strengthened itself, whether by social movements or specialised non-governmental organisations. Finally, since the late 1990s, we can also note the expansion of civil society's transnational activity, defining international arenas as places that offer restrictions and opportunities and allow the forging of contentious politics strategies (Tarrow 2005).

There is an increasing consensus among Brazilian academics to regard foreign policy as a continuum of the domestic political-economic dynamics and, therefore, a reflection of the disputes among the multiple interests in society that compete for access to the decision-making process. In other words, the understanding of foreign policy is increasingly moving away from the Realist readings of State Policy and closer to the field of public policies, whose decision-making process should be subjected to democratic controls (Pinheiro and Milani 2011). Academic production has made progress in explaining and analysing various aspects of this reality of Brazilian foreign policy, namely, its new institutional arrangements between governmental actors and the changes and continuities in the role traditionally filled by the Brazilian diplomatic bureaucracy. The diversity of analyses touches on perspectives related to: the constitutional competencies to act in distinct stages of the policy cycle on the part of the Executive (Sanchez et al. 2006; França and Sanchez 2011) and the Legislative Branches (Lima and Santos 2001; Soares 2005; Figueira 2009); the internationalisation of sectorial policies and the broadening of foreign policy agendas (Milani and Pinheiro 2013); the pluralisation of foreign policy's agents (Cason and Power 2009); and the effects of the change in the correlation of forces between the factions of the national bourgeoisie on foreign policy (Berringer 2015).

Nevertheless, much less attention has been paid to the analysis of the democratisation of its decision-making processes and the participation of non-governmental actors, especially organised civil society, which are the central theme of the present analysis. This article seeks to analyse the democratic quality of dialogue between the Executive Branch and civil society, drawing on the advances made by studies on democratic participation. The analysis is supported by the recent analytical construction that emphasises Brazilian foreign policy's plurality of actors and agendas, as well as the horizontalisation of its decision-making process. Against this background, the article is based on the premise of Brazilian foreign policy as a public policy, and therefore subject to democratic controls. It seeks to identify similarities and differences in formats, actors, and motivations that comprise the participatory institutions of foreign policy. ${ }^{1}$ For this purpose, the participation of civil society will be analysed in three spheres of foreign policy: international multilateral negotiations (commercial and sectorial); MERCOSUR as an example of a regional integration mechanism; and South-South development co-operation.

The adopted focus is supported with criteria proposed by the literature on democracy, specifically that which is concerned with participatory and deliberative democracies. These criteria include: the initiatives' formalisation degree and participation level; the participant's representativeness, diversity and extent; and the quality of deliberation. 
Furthermore, Foreign Policy Analysis is adopted as an analytical tool to gain access to the domestic and external factors that influence the decision-making processes in foreign policy, contributing to an understanding of the domestic and international dynamics that may exert influence in the policy's opening to the participation of non-governmental actors in the three selected spheres. Thus, through literature review and participant observation, the article seeks to analyse the main characteristics of civil society participation in Brazilian foreign policy in different sectors of the Executive with a competency to act internationally.

In this sense, the article's focus includes government-led dialogue initiatives in the realm of foreign policy, which have been responding to the new context with administrative reforms and a gradual opening to an interlocution with new actors. The article seeks to contribute by recognizing the challenges to be considered in this process of opening and dialogue. By identifying how the promotion of civil society participation in each of the selected cases occurs, the article aims to contribute to the understanding of the exercise of vertical control between the state and society and to formulate institutional arrangements that consider the current context of Brazilian foreign policy.

In terms of overall results, it is possible to state that civil society participation in Brazilian foreign policy has a discretionary character, with a high degree of informality, a non-binding nature, and without criteria for participants' representativeness. In general, promotion of dialogue and civil society participation in Brazilian foreign policy responds to three factors: (i) the participation of other institutions within the Executive Branch in the agendas of foreign policy aside from the Ministry of Foreign Relations; (ii) the existence of a coalition surrounding a given theme that unites sectors of civil society with a history of international activity or specific capabilities for dialogue with highly specialised bureaucracies; and (iii) opportunities in the international or domestic sphere that incentivise participation or cause some type of constraint for non-participatory initiatives.

The following sections contain first a brief analysis of Brazilian foreign policy's current context in light of global and domestic changes, highlighting the impact that these have on its decision-making process. This is followed by an appraisal of the arguments regarding the relationship between foreign policy and democracy that strengthen or challenge foreign policy's singularity when compared to other public policies, thus permitting a link with the literature on citizen participation. The third section introduces the main criteria that support the analysis regarding the democratic quality of civil society participation in foreign policy, which is then carried out in the fourth section. The fifth and final section synthesises the main arguments developed and explores some analytical implications.

\section{The context of Brazilian Foreign Policy and the implications for its democratisation}

Brazil's international insertion has gone through substantive changes in the last fifteen years, with the adoption of a proactive and pragmatic foreign policy as a pillar of the newly elected government of ex-president Luiz Inácio Lula da Silva. Staking out a more 
ambitious and reconfigured international position as a strategic instrument of domestic development, this strategy confronted the idea - still prominent at the time - of foreign policy as an accessory to the maintenance of macroeconomic stability and international credibility (Hirst et al. 2010).

Benefitting from global economic transformations, especially the rise in commodity prices and increased tendencies by emerging economies to strengthen a multi-polar international order, the country intensified its political and economic activity in various global and regional areas, such as: the G20; the creation of the inter-regional integration mechanism BRICS (Brazil, Russia, India, China, and South Africa); the thematic and geographic broadening of regional integration's processes; greater political and economic exchange with Africa; the intensification of presidential diplomacy; and greater protagonism in the multilateral system and the debates on its reforms. The Brazilian engagement in international development co-operation also acquired unprecedented dimensions, with a substantial increase in its South-South development co-operation that - as an instrument of foreign policy - materialises the combination of the principle of solidarity with the intensification of political, social, and economic relations. Finally, the growth of international operations of public banks must be considered, such as the support of the National Development Bank to Brazilian companies' internationalisation.

If, on the one hand, changes in the international order like the intensified internationalisation of capital or the increased recognition of the need for the protection of global public goods contributed to an enlargement of the transnational character of national and local agendas, then, on the other, Brazilian policies themselves have become internationalised, motivated in large part by the intensification of South-South relations. There are innumerable variables that explain the growing internationalisation for each of the Brazilian sectorial policies, such as the international context of its insertion, the existence of multilateral or regional regimes, each agenda's context and the priority given to it domestically, the existence and activity of domestic constituencies, or the media attention given to these (Pinheiro and Milani 2011).

Besides this broadening of foreign policy's agendas, the strengthening of Brazil's identity as a middle power of the global South capable of acting as a mediator in international relations (Leite et al. 2014) - or, in the definition of Keohane (1969), as a system-affecting state - also contributed towards increased domestic public attention to Brazilian foreign policy, as well as increased international expectations. This new role of an 'emergent' Brazil combined with the narrative constructed about its identity also becomes an object of democratic control on the part of Brazilian civil society, functioning as an extension of internal disputes surrounding the development policies promoted by Brazil, both domestically and abroad.

If the economic opening and the intensification of internal distributive impacts conditioned the broadening of foreign policy's agendas to new specialised actors and the increasing dispute for access to the decision-making process by sectors of society, this new scenario intensified a series of political and analytical challenges. Among them is the need for the establishment of new arrangements for consensus building in the formulation of 
foreign policy guidelines, to achieve greater legitimacy, representativeness, and, at the same time, co-ordination. ${ }^{2}$

In short, we are dealing with a change in the nature of the decision-making process of Brazilian foreign policy that, traditionally, enjoyed the autonomy and legitimacy of being exclusively defined by the Ministry of Foreign Relations. This autonomy and legitimacy was due either to the regime of industrial protection prior to the economic opening, which controlled the central content of foreign policy either because the Ministry kept a certain distance from public opinion or due to its highly specialised and qualified bureaucratic corps, the guarantors of legitimacy in the face of other governmental and social actors (Pinheiro 2003, cited in Figueira 2009). The commercial opening, the democratisation of the state and of public policies, and consequently the broadening of agendas, actors, and interests contribute to a context where the legitimacy of foreign policy decision-making process is no longer centred in bureaucratic authority, but in its democratic formulation (Pinheiro and Milani 2013). ${ }^{3}$

Domestically, two factors add important elements to the analysis of the promotion of civil society participation in foreign policy decision-making processes: the democratisation of Brazilian public policies and the strengthening and internationalisation of Brazilian civil society.

Brazil has experienced an important stage of institutional innovation in the last 20 years with the large-scale institutionalisation of participatory spaces, generating an unprecedented participatory context. The participatory innovations gained momentum beginning with Brazilian re-democratisation in 1988, mainly at the local level. From 2003 onward, with the arrival of the Worker's Party to the Presidency, a new impetus was given to the promotion of institutional initiatives of citizen participation, consolidating and broadening the experiences to the federal level. Nevertheless, the formalisation of participation in foreign policy, in the form of the National Council on Foreign Policy, despite being debated in the federal government and defended by civil society, continues only as a proposal.

Regarding democratisation and civil society's influence in the public sphere, Dagnino (2004) highlights a 'perverse confluence' between the minimal state neoliberal project, with responsibilities being transferred to civil society, and the democratising and participatory project that emerges with the end of the authoritarian regime. Thus, the exponential growth in the number of non-governmental organisations in Brazil combines responses to the liberal imperative and 'outsourcing' of state responsibilities with the recovery of popular movements' traditional agenda of citizenship and political participation, which had been aborted by the dictatorship (Steil and Carvalho 2001).

Finally, structural factors also contributed to civil society internationalising itself. Among these are: the impact of the economic adjustments of the 1990s, which magnified the connection between global decisions and local impacts, perceived in a similar manner in various medium- or low-income countries; the expanded opportunity to participate in international areas, as in the case of United Nations conferences; and the evolution of communication and transportation systems, which facilitated connections between diverse actors. All those changes culminated in the intensification of contentious politics 
at the global level, well represented in the regional and global spheres by the campaign against the Free Trade Area of the Americas and the anti-globalisation protests that began in Seattle. Organised sectors of Brazilian civil society with a proven history of influence on national policy and of engagement in international networks contribute to the formulation of narratives and recommendations that seek to influence Brazilian international insertion in certain sectors. In this sense, it is not possible to dissociate civil society international engagement from its growing demand for participation in the decision-making process of Brazilian foreign policy.

\section{Foreign policy and democracy}

Foreign policy is traditionally treated as a unique policy and as different from other domestic public policies (Badie 2009). The defence of foreign policy's uniqueness contributes to how it is configured as one of the few policies that do not demonstrate significant changes in its interface with civil society. In other words, even in democratic countries, foreign policy seems to have escaped the 'democratic condition' (Lopes 2013) and continues as a restricted and secret domain (Badie 2009), presenting itself as one of the most difficult policies over which to exercise democratic control (Dahl 1999), and whose decisionmaking process presents a low level of democratic quality (Dahl 1950).

Sceptical positions, through the Realist prism of International Relations, reinforce foreign policy specificities among public policies, and its difficulty in being made compatible with democracy. Among them we can identify arguments centred on the irrationality of democratic politics, subject to immediacy and disputes related to the access to power through elections that would put the long-term 'national interest' at risk (Lopes 2013; Villa and Tostes 2006), or, furthermore, the fact that decentralisation of foreign policy decisions risks the credibility of promises made to the international community (Lima 2000). Finally, the defence of the technical and specialised character of foreign policy and the reinforcement of the class identity of diplomatic bureaucracies (Badie 2009; Hill 2003a) contribute to differentiating foreign policy from other public policies. These arguments are based on the heritage of a foreign policy concept that can be subsumed in inter-state dynamics (Biersteker 2002), and go back to the construction of the modern state and its 'individualised' insertion into the international scene, based on premises of autonomy and sovereignty and it being a defender and representative of the national interest (Morgenthau 1978).

Within the extensive field known as Foreign Policy Analysis, various arguments strengthen the artificiality of a separation between foreign and domestic policy, and empirically prove that foreign policy's decision-making process responds as much to the disputes and interests of different domestic groups as it does to factors present in the international arena (Milner 2007; Keohane and Milner 1996).

Those analyses centred on the decision-making process demonstrate the influence of the organisational and bureaucratic processes on foreign policy decisions, thus highlighting the institutional architecture in which ministries, agencies, states, and municipalities take part. The alleged rationality and the national interest's defence in the decisions made 
by the head of the Executive Branch or of the Ministries of Foreign Relations thus find their empirical support to be challenged (Allison 1969).

Also, including the relationships between the roles of public opinion, elites and pressure groups as analytical components, Foreign Policy Analysis inquires about how the domestic determinants, related to the different natures of political systems, can affect the decisions in foreign policy. Drawing on the concept of Domestic Structure to prove the importance of operationalising the institutional arrangements and coalition-building processes that channel the social demands within a political system, Risse-Kappen (1991) sheds light on the importance of understanding the exact nature of the link between society and government. Putnam (1988) draws attention to the importance of an analysis anchored in a theory of domestic politics to explain actors' preferences and how these impact the dynamics of international negotiations' domestic ratification. According to this author, this is a dynamic peculiar to democratic governments, but not necessarily realised in a democratic way or restricted to the formality of Congressional approval, as it also presumes the support of groups, bureaucracies, and public opinion. Furthermore, it points to the importance of the international context and its influence on foreign policy, configuring a two-way process where international pressures exert effects on the domestic environment, specifically in terms of the alteration of equilibriums and positions that can increase or diminish the range of possibilities for the success of a negotiation, or win-sets.

The argument for the complexity and specificity of foreign policy's agendas and, consequently, the necessity of specialisation and centralisation for its guidance presupposes that a democratic debate would diminish the efficiency and efficacy of foreign policy decisions in relation to its objectives in the short and long term. In the long term, the lower technical capacity and disinterest of the legislative branch, as well as the lack of interest and informed opinion from the citizenry in general, would contribute to irrational, manipulative, or immediate opinions. In the short term, in those cases that call for responses to imminent threats, the time necessary for democratic debate would make timely decision-making impossible. Nonetheless, these arguments are self-referential and ignore (i) the fact that democratic debate could serve to broaden and redefine the very objectives of foreign policy in the long term (Nincic 1992, cited in Villas and Tostes 2006); (ii) the empirical proof of existing mobilisation in the Legislative branch (Martin 2000); (iii) that even in the Executive, foreign policy decision-making is not centralised (Pinheiro and Milani 2013); and (iv) that public opinion exerts pressure on the decision-making process (Holsti 1992).

The defence of foreign policy's uniqueness due to its complexity is also not able to present proof that differentiates foreign policy from other public policies in this respect. It ignores, for example, the debate about the impossibility of providing, from a technical-rational or sectorial logic, satisfactory responses to 'wicked problems' (Brugué et al. 2011). ${ }^{4}$ Paradoxically, according to this literature, the complexity determines the absence of a single best solution and, therefore, requires more deliberation than specialised knowledge. In other words, it is dialogue, based in rules and deliberative procedures, that allows citizenry and policy-makers to arrive at shared moral judgments and political alternatives (Majone 1989). 
Another relevant debate for understanding the relation between foreign policy and democracy concerns the transformations which globalisation imposes on the role traditionally performed by modern states. Held (2006) points to the fact that the debate about democracy had taken for granted the equivalency between state, territory, and sovereignty. According to this author, democratic theory has not adequately formulated the implications of the dissociation between these dimensions and the impact of multilateral governance and international organisations' decision-making processes, the extension of international law, and the growth of transnationalism in areas such as culture and the environment. These dynamics challenge the assumptions of democratic theory regarding the delimitation of community based on territory (demos) (Held 1999; Sørensen 2006).

Nevertheless, from a perspective that advocates a more dialectical view of the relationship between globalisation and the changing role of modern states, we can list the arguments: (i) the assignment of state authority for governance at the supra- or inter-state levels allows the submission of regional and global processes' to the political control of states, which continue as central actors in the construction of multilateral norms and organisation; (ii) sovereignty is a legal institution that involves constitutional independence and regulatory capacity; (iii) there does not exist an international demos outside the limits of states (Sørensen 2006); (iv) there never existed a 'glorious' past for the state, in which it had been able to maintain absolute control over trans-boundary flows (Badie 2009).

Thus, in spite of the fact that globalisation and the increase of economic interdependence have an impact on the sovereignty of states, the state is still considered the best focal point for decisions in international and multilateral spheres, and thus allows democratic control. Therefore, theoretical and practical demands for a greater politicisation and domestic legitimacy of foreign policy decision-making process gain relevance, since it offers one of the few points where it is possible to unite agency, democratic control, and responsibility in this interconnected world (Hill 2003b).

\section{An analysis of the democratic quality of civil society participation in Brazilian foreign policy}

To analyse the quality of civil society participation in Brazilian foreign policy, we take as our analytical point of departure the following premises about its decision-making process: (i) normatively, the whole structure of the Executive Branch presents competencies to define the agenda and formulate or implement foreign policy (Silva Spécie, and Vitale 2010); (ii) the growing 'internationalisation' of Brazil's Executive structure is atomised in response to the dynamic and multifaceted global agenda (Hirst 2011); (iii) the power of agency of the governmental and non-governmental actors outside the MRE has grown (Pinheiro and Milani 2011), bringing with it different interpretations about international agendas, the role of the state, and opportunities and constraints at the international level.

In light of the elements listed here, the central question that arises is: If the political legitimacy of foreign policy's decisions does not hold up in the defence of a univocal national interest (given that this is non-existent), but rather in the exercise of democracy 
in its formulation, how do we reveal the plurality of interests in dispute and promote a democratic formulation of foreign policy with domestic constituencies' participation?

Seen in these terms, and presuming foreign policy to be a public policy, it is possible to build bridges with the intellectual production on Brazilian participatory institutions. In the last decade, the scale of and increasingly closer relationship between citizen participation and policy-making resulted in a national research agenda that seeks to advance beyond the normative consensus on the democratic value of citizen participation and sheds light on domestic participatory institutions' challenges. Considering that representatives of the citizenry in those participatory institutions have authority to influence a broad spectrum of governmental issues at all administrative levels of the federation, questions of representativeness (Lavalle et al. 2006; Avritzer 2007) and the effective contribution of these institutions to policy-making emerge as central to the debate (Avritzer 2011; Pires 2011; Pogrebinschi and Samuels 2014).

Furhermore, an expressive contribution of the literature on contemporary democracy is comprised of issues concerning the deliberative quality of participatory initiatives and their potential in recovering democracy as an idea of community life (Dewey 1927: 48), or strong democracy (Barber 2004), against the weaknesses of a representative system based on an instrumental and liberal democracy. The institutional or organisational design of citizen participation and its relation to the effectiveness of participatory institutions is also an object of analysis and discussion in the literature regarding participatory democracies (Fung and Wright 2003; Avritzer 2008).

Therefore, the different participatory initiatives in the context of Brazilian foreign policy will be analysed in light of criteria such as: who participates in the initiatives (extension of participation, degree of openness, representativeness of the participants in the face of the totality of interested parties); how this participation functions (methodologies used; whether they are routine or occasional; quality of the information provided; degree of participation - information, consultation, or deliberation); institutionality of participation (whether it includes some degree of institutional formalisation, whether through regulation or at least regularity, institutional locus, design, and origin of initiative). ${ }^{5}$ In addition, the principal motivations that explain the impetus behind the initiative's promotion are analysed, understanding that these determine the formats and results of the participatory initiative (Pomeroy 2009).

\section{Participation of civil society in Brazilian Foreign Policy}

The process of adaptation to a new context led the MRE to create new channels of dialogue with civil society (Mesquita 2012). However, it is not clear if this process responds to the existence of a coherent guideline. On the one hand, there is the concept of public diplomacy, present in the internal document 'Reflections on Brazilian Foreign Policy' (1993), which acts as a guide to the actions of transparency and communication. On the other hand, there are no clear indications on how these guidelines translate into promotion of citizen participation. ${ }^{6}$ 
A myriad of dialogue initiatives in various formats, either sporadic or more constant, have been established in the last two decades. These initiatives cover various aspects of Brazilian foreign policy agenda, although they have not been exclusively carried out by the Ministry of Foreign Relations. ${ }^{7}$ Some of the identified formats include work groups, informal meetings, seminars, committees, national consultation sections, business councils, and - most recently - public consultations. It is worth emphasising that some of these are common citizen participation mechanisms promoted in other Brazilian public policies, which also include public hearings, councils, and national conferences (Brasil 2012). Nevertheless, the academic debate on citizen participation in Brazil rarely considers the field of foreign policy, and vice-versa.

Furthermore, the participation of civil society can also occur directly in the international sphere, in co-ordination with the diplomatic bureaucracy, as in the case of MERCOSUR (Socio-Economic Consultative Forum of MERCOSUR, Specialised Networks), of the CPLP (Civil Society Forum of the Community of Portuguese-Language Countries), or of the United Nations.

In order to understand the current state of civil society participation in foreign policy and its democratic quality, we sought to analyse three areas of Brazilian foreign policy: multilateral international negotiations, regional integration and the case of MERCOSUR, and South-South development co-operation. Analysis by area allows a broader vision of participation tendencies, without focusing on individual mechanisms or on specific themes that can represent particular dynamics. Finally, the existence of previous studies that analyse the interlocution between government and society contributed to the definition of the three areas.

In the case of participation in multilateral trade negotiations, the majority of the literature centres on the preferences and strategies of private sector interest groups and civil society, analysing domestic and external conditions to explain positions assumed and negotiation results according to the preferences of each group. Influenced by the theory of two-level games (Putman 1988), the intellectual production also analyses issues like credibility, legitimacy, and bargaining power in negotiations (Veiga 2007; Carvalho 2010; Santana 2001; Oliveira and Milani 2012; Carvalho 2003).

Nevertheless, they offer elements to understand the format of the dialogue established among non-governmental actors and diplomatic bureaucracy. Main characteristics of this participation can be synthetised as (i) informality, low institutionalisation, and discretion of the diplomatic bureaucracy regarding the promotion of participatory channels - relating to who to invite, when to meet, agenda-setting, and dialogue format definition; (ii) lack of information offered by the diplomatic bureaucracy; (iii) informational or consultative character of the initiatives; (iv) low representativeness of the participants invited by the Executive; and (v) search for legitimacy of pre-established positions by the bureaucracy (Veiga 2007; Carvalho 2003, Santana 2001; Farias and Ramanzini Júnior 2010). Finally, although it is challenging to establish relations of causality and to attribute the effectiveness of the final content of participation in negotiations, a seemingly unanimous evaluation found among studies on the subject concerns the low capacity for influence that these channels exercise on Brazilian positions (Veiga 2007; Santana 2001; Carvalho 2010). 
With respect to the discretionary and informal character, the academic production on the subject identifies that an asymmetry of information between diplomatic representatives and non-governmental actors contributes to a situation where the power for defining the agenda is concentrated in the government. This situation was particularly relevant at the beginning of the 1990s, the moment in which the first initiatives of dialogue occurred. As such, commercial sectors, social movements and labour unions searched for autonomous strategies to transcend the dependency on the government for information. In the case of civil society actors, their history of international engagement contributes to their ability to access information from the transnational networks of social movements and unions. The business sector, for its part, organised domestically to generate the necessary knowledge and expertise for more informed relations with the government (Carvalho 2010).

This process also generated new institutionalities, such as the creation of the Brazilian Business Coalition (CEB), the Permanent Forum of International Agricultural Negotiations, and the Brazilian Network for the Integration of the People (REBRIP), which contributed to greater representativeness of those sectors in the initiatives promoted by the Ministry of Foreign Relations, who initially invited social representatives without defining representativeness criteria (Santana 2001; Carvalho 2003; Oliveira and Milani 2012; Veiga 2007). Another relevant aspect identified in the literature concerns the fact that dialogues were also promoted by other government ministries, such as the Ministry of Agriculture and Livestock, the Ministry of Agrarian Development, the Ministry of Development, Industry and Trade, and the Ministry of the Environment, which imposes co-ordination challenges for the MRE (Veiga 2007; Carvalho 2013).

In the case of international negotiations on social themes, we can identify similarities with relation to discretionary, informality, lack of information, the consultative and informative character of initiatives, and the lack of criteria for representativeness of participants. Nevertheless, the central motivation identified is the legitimacy in the face of the international system and response to the recommendation of the UN system itself regarding the need to establish participatory processes (Mesquita 2012), as well as the existing mobilisation and demands for participation among Brazilian civil society (Santoro 2012).

Characterised by an initial moment of resistance to and distrust of the Brazilian government in opening channels for dialogue, civil society participation in the thematic negotiations consolidated via informal meetings and informative seminars. The incorporation of civil society representatives in the negotiating delegations is still not a consolidated practice, and many times the dialogue during international negotiations happens by the initiatives of some organisations themselves that have the resources to accompany the process in an autonomous way. Most recently, the MRE established a consultation to inform the Brazilian contribution to the new agreement under the United Nations Framework Convention on Climate Change (2014). This was open to individuals and social organisations throughout the country to contribute to online via questionnaire and face-to-face meetings, establishing a more structured format of participation. Nonetheless, this is still not a consolidated practice, as is evident in the process for the Post-2015 Agenda, which 
in spite of formal petitions on the part of a broad spectrum of civil society, with strong leadership by the Brazilian Association of Non-Governmental Organisations (ABONG), did not include a structured and transparent process of civil society participation within the calendar of international negotiations.

Participation at the level of regional integration, namely MERCOSUR, can occur directly in the regional institutions, or in the domestic sphere, via the Participatory Social Program of MERCOSUR, co-ordinated by the Presidency's General-Secretariat and by the Ministry of Foreign Relations, which establishes a permanent dialogue between government and civil society around the theme of integration in MERCOSUR. The program, although it presents challenges related to democratic quality (Ramanzini Júnior and Farias 2015), includes greater institutionalisation, representativeness, and diversity of participants. Created by presidential decree in 2008, it includes a Council, periodic meetings, and a draft resolution that envisions composition and functioning. Delegates from civil society can participate and forward proposals to MERCOSUR's Presidential Summits.

The fact that MERCOSUR itself includes formal spaces of participation influenced the need to establish a domestic space for the co-ordination of Brazilian civil society's position (Mesquita 2013). The consensus on the need for societies to engage in deepening regional integration and co-operation also contributed to the opening of MERCOSUR to civil society (Ramanzini Júnior and Farias 2015). It is also worth emphasising that the Presidency's General-Secretariat is the body responsible for social participation at the level of the Federal Executive and, therefore, aside from accumulating specific knowledge and experience about the subject, its own mission contributes to the idea of a more elaborate, wide-ranging participation.

Furthermore, in relation to MERCOSUR, civil society participation in the Specialized Meeting on Family Agriculture (REAF) is recognised as one of the forums most open to civil society participation (Alemany and Leandro 2006). ${ }^{8}$ The REAF emerges as a confluence of the interests of the Brazilian government and a group of rural labour unions and social movements. For the Brazilian government, in particular the Ministries of Agrarian Development and Foreign Relations, the REAF would confer coherence on foreign policy in terms of both national and international interfaces. At the national level, this would be through policies supportive of family farming, and in the international sphere, through presenting alternatives to the model of regional integration proposed in the negotiations for the Free Trade Area of Americas, which were underway at that time. For the Brazilian social organisations mobilised to influence regional integration's process, the REAF represents an opportunity for strengthening their agendas and for broadening their spaces of political advocacy, with repercussions beyond the regional context (Bülow and Carvalho 2012).

Finally, in the framework of South-South development co-operation, we identify different - and incipient - modalities of civil society participation, such as civil society implementing projects, whether by government's invitation or via their own strategies with government support (Schmitz 2014; Marcolini 2014; Suyama and Pomeroy 2014), and civil society participation, promoted by the government, in debates around specific co-operation initiatives (Leite et al. 2015). ${ }^{9}$ 
In this second modality, participation is almost non-existent and dispersed among the ministries that promote the initiatives. In some cases, organised civil society is called upon to share, sporadically, their experience in the framework of specific projects (Santos 2013). One exception to the rule is the case of the National Council of Nutritional and Food Security (CONSEA), which participated regularly in the meetings of the Purchase from Africans for Africa project (PAA Africa) promoted by the General Coordination for International Action Against Hunger (Ministry of Foreign Relations) together with the Ministry of Social Development (Beghin 2014; Leite et al. 2015). In this case, it is worth highlighting that the participation was grounded in the National Plan of Nutritional and Food Security, which clearly lays out social participation in the area of international negotiations and projects of international co-operation (PAA Africa 2015). On account of the dispersed and decentralised character of Brazilian South-South co-operation (Leite et al. 2014), it is expected that civil society's participation responds to different drivers and goals, as well as acquires different formats (Milani 2008; Pomeroy 2009).

\section{Conclusion}

A brief review of some of the participatory initiatives in foreign policy agendas indicates the absence of guidelines and criteria for the establishment of dialogue with civil society, which is in large part characterised by its informality, low institutionalisation, and discretionary nature. As a result, we identify a series of limitations to the quality of participation, such as an asymmetry of information, lack of structured and transparent methodologies, and a lack of criteria concerning the diversity and representativeness of participants.

Against this background, the variety of actors in the Executive Branch that promote civil society participation in foreign policy agendas reproduces different conceptions of participation that are reflected in initiatives with different formats. While not seeking to establish causality relations, it is possible to identify a body of evidence that indicates that the promotion of participatory initiatives is responding to domestic and international determinants related to each subject in question, as well as to the capacities and strategies of mobilisation of non-governmental sectors.

Analysis of civil society participation in Brazilian foreign policy is still incipient, and there is a growing interest in this subject in the research agenda of Internationalists. Future investigations can promote a more structured dialogue with the extensive Brazilian intellectual production on participatory institutions, and a more profound analysis of single aspects of foreign policy participatory initiatives. In this way, some of the aspects discussed by this literature touch upon the effectiveness of participation, the influence exerted on the decisions, and the forms of representation exerted by civil society.

Another field for analysis concerns the understanding of how civil society international engagement adds to its domestic strategies regarding foreign policy. In this sense, considering that studies on transnational activism point to the international arena as a continuum of political opportunity structures, it should be possible to establish links between the fields of research on collective action and Foreign Policy Analysis, understanding that the first offers a series of analytical tools that can contribute to understanding the 
role of civil society, generally spurned by the second, whose central focus continues to be the state and governmental actors.

\section{Notes}

1 We use the definition of participatory institutions proposed by Avritzer (2005: 45): 'differentiated ways of incorporating citizens and civil society associations in the deliberations on policy.'

2 It is not possible to refer to representativeness without mentioning the role of the legislative branch. Nonetheless, the principal focus of the present analysis resides in establishing dialogues with the intellectual production that, in the field of democratic theory, is concerned with the participation of civil society as the existence of deliberative processes that gather together the representatives of civil society and the executive branch, seeking to influence the formulation and implementation of policies and governmental programmes, in the framework of a representative democracy. For a review of the literature on the participation of the Brazilian legislative power in foreign policy, see Figueira (2009).

3 This does not mean that the MRE does not continue to be the central actor in the definition and formulation of foreign policy, but rather that it is no longer the exclusive actor in the process (Pinheiro and Milani 2013). In the area of constitutional competencies in the matter of Foreign Policy, little was changed in the democratic constitution of 1988 (Sanchez et al. 2006), maintaining the Executive Power as the central actor. Nevertheless, this provided general principles for the action of the State in international policy that had an impact on the capacity for action of the various actors within the Executive, Legislative, and Judiciary Powers, ensuring that the decision-making process regarding international action would also be in the framework of the democratisation of public policies carried out by other governmental bodies (Milani 2011).

4 'Wicked problems' are defined as those problems characterised by uncertainty and interdependence of the aspects they present, as well as the diversity of actors, values, and interests involved (Heald and Alford, cited in Brugué et al. 2011).

5 Criteria adapted from Arnstein (1969), Parés \& Castellà (2009), and Brugué (2009).

6 Nor does there exist conceptual clarity on the meanings of public diplomacy in the literature, which variously approaches the concept from the perspective of opening to dialogue with civil society, or subnational entities, or even as a media strategy of national and international positioning (Snow 2009).

7 There is no systematic information on the different initiatives for dialogue with non-governmental actors undertaken by the Ministry of Foreign Relations. In addition to the initiatives discussed in this article, albeit with no intention to present them as an exhaustive list, we can cite: Dialogues on Foreign Policy (2014); consultation to support the process of preparation of the 'nationally-determined contribution' presented to the negotiations of the United Nations Framework Convention on Climate Change (2014); meetings surrounding the agenda of BRICS; the Inter-Ministerial Working Group on International Business in Goods and Services (GICI); national sectors of consultation (SENALCA and SENEUROPA); and the Permanent Business Committee of the MRE. Furthermore, in connection with the Presidency's General-Secretariat, we identify the 'Meeting for Foreign Policy, Social Dialogue, and Citizen Participation' (2011), and with the Ministry of Environment, the 'Consultation with International Civil Society: The Path to Rio+20' (2011).

8 The authors evaluate that REAF, along with the Specialised Meeting of Women (REM), have the most developed internal rules of functioning when compared to the other participatory spaces of the Common Market Group. While the Brazilian government proposed the creation of REAF, REM was created as a response to the pressure exerted by women's movements (Orsino 2009).

9 We may also highlight civil society engagement in South-South development co-operation that are not promoted by the government, such as (i) 'activist co-operation' (Marcolini 2014; Berrón and Brant 2015); (ii) autonomous organisation of initiatives for the production and dissemination of information aimed at public opinion and specialists, aiming to monitor and control the policy of co-operation in its entirety (Ciommo and Amorim 2015; Leite et al. 2014; Marcolini 2014); (iii) engagement of Brazilian civil society in other countries focusing on the resistance to co-operation projects promoted by the Brazilian government. 
An emblematic example of this is the alliance between Brazilian and Mozambican social movements and their contentious activities in the face of the trilateral co-operation project PROSAVANA (Shankland and Gonçalves 2016); (iv) finally, it is worth emphasising the growing number of studies that analyse Brazilian South--South development co-operation decision-making processes and the influence of civil society. See Leite et al. (2014) for an overview and Leal (2013) and Leite et al. (2015) for co-operation in Food and Nutritional Security. Even assuming that this autonomous organisation of civil society affects its strategies of influencing foreign policy, it does not form part of our analysis, as the focus established here is restricted to civil society participation in government-led initiatives.

\section{References}

Albuquerque, Felipe L R de. 2013. Atores e agendas da política externa brasileira para a África e a instrumentalização da cooperação em segurança alimentar (2003-2010). MsC. Universidade do Estado do Rio de Janeiro

Alemany, Cecilia and Beatriz Leandro. 2006. Análisis y propuestas para la participación ciudadana en el MERCOSUR. Montevideo: Friedrich Ebert Stiftung.

Allison, Graham T. 1969. 'Conceptual Models and the Cuban Missile Crisis'. The American Political Science Review 63 (3): 689-718.

Arnstein, Sherry. 1969. 'A ladder of citizen participation.' Journal of the American Institute of planners 35 (4): 216-224.

Avritzer, Leonardo. 2008. 'Instituições participativas e desenho institucional: algumas considerações sobre a variação da participação no Brasil democrático.' Opinião Pública 14 (1): 43-64.

. 2011. 'A qualidade da democracia e a questão da efetividade da participação: mapeando o debate.' In Roberto Rocha Pires (ed), Efetividade das instituições participativas no Brasil: estratégias de avaliação Brasília: Instituto de Pesquisa Aplicada. pp. 13-28.

2007. 'Sociedade Civil, Instituições Participativas e Representação: Da Autorização à Legitimidade da Ação' Dados 50 (3): 443-464.

Bülow, Marisa von and Priscila Delgado de Carvalho. 2012. 'Entre o nacional e o transnacional. O caso das organizações da agricultura familiar no Mercosul.' In Maria da Glória Gohn and Breno M Bringuel (eds), Movimentos Sociais na Era Global. Petropólis: Vozes. pp. 229-246.

Badie, Bertrand. 2009. O diplomata e o intruso. Salvador: EDUFBA.

Barber, Benjamin. 2004. Democracia Fuerte. Córdoba: Almuzara.

Beghin, Nathalie. 2014. A Cooperação Brasileira para o Desenvolvimento Internacional na Área de Segurança Alimentar e Nutricional: Avanços e Desafios - Onde estamos e para onde vamos? Brasília: INESC.

Berringer, Tatiana. 2015. A Burguesia Brasileira e a Política Externa nos Governos FHC e Lula. Curitiba: Appris.

Berrón, Gonzalo and Maria Brant. 2015. 'Expertise, Disputa Política ou Solidariedade? Variações sobre o Engajamento da Sociedade Civil Brasileira na Cooperação Sul-Sul'. In Haroldo Ramanzini Júnior and Luis Fernando Ayerbeeds (eds), Política externa brasileira, cooperação sul-sul e negociações internacionais. São Paulo: Cultura Acadêmica. pp. 251-284

Biersteker, Thomas J. 2002. 'State, Sovereignty and Territory.' In Walter Carlsnaes, Thomas Risse and Beth A Simmons (eds), Handbook of International Relations. London: SAGE. pp. 207-235. 
Brasil. 2012. Relatório Participação Social na Administração Pública Federal: Desafios e Perspectivas para a Criação de uma Política Nacional de Participação. Brasília: Ministério do Planejamento. Brugué, Quim. 2009. 'Calidad Democrática: de la debilidad liberal a la fuerza deliberativa.' In Marc Parés (ed), Participación y calidad democrática: Evaluando las nuevas formas de democracia participativa. Barcelona: Ariel. pp. 121-138

Brugué, Quim, Ramón Canal and Palmira Payà. 2011. ‘¿Inteligencia administrativa para abordar problemas "malditos"? (El caso de las comisiones interdepartamentales en el Gobierno de Cataluña).' X Congreso de la Asociación Española de Ciencia Política. Murcia: AECPA.

Carvalho, Maria Izabel. 2003. 'Estruturas Domésticas e Grupos de Interesse: A Formação da Posição Brasileira para Seattle.' Contexto Internacional 25 (2): 363-401.

2010. 'Condicionantes Internacionais e Domésticos: O Brasil e o G-20 nas Negociações Agrícolas da Rodada Doha.' DADOS 53 (2): 405-445.

Cason, Jeffrey W and Timothy J Power. 2009. 'Presidentialization, Pluralization, and the Rollback of Itamaraty: Explaining Change in Brazilian Foreign Policy Making in the Cardoso-Lula Era.' International Political Science Review 30 (2): 117-140.

Ciommo, Mariella Di and Alice Amorim. 2015. 'Brazil as an international actor: Drivers for development cooperation.' Development Initiatives. Available at: http://devinit.org/wp-content/uploads/2015/04/Brazil-as-an-international-actor.pdf [accessed on 9 June 2015].

Dagnino, Evelina. 2004. 'Construção democrática, neoliberalismo e participação: os dilemas da confluência perversa.' Política e Sociedade 3 (5): 139-64. .

Dahl, Robert A. 1999. 'Can International Organizations be democratic? A skeptic's view.' In Ian Shapiro and Cassiano Hacker-Cordón (eds), Democracy's Edges. Cambridge: Cambridge University Press. pp. 19-36.

. (1950). Congress and Foreign Policy. New York: Harcourt, Brace and Company.

Dewey, John. 1927. The Public and Its Problems. Chicago: Swallow.

Farias, Rogério de Souza and Haroldo Ramanzini Júnior. 2010. 'Against the Tide: Democratization and Foreign Policy in Brazil.' $7^{\circ}$ Encontro Nacional da Associação Brasileira de Ciência Política. Recife: Associação Brasileira de Ciência Política.

Figueira, Ariane C Roder. 2009. Processo Decisório em Política Externa. PhD, São Paulo: Universidade de São Paulo.

França, Cassio and Michelle Ratton Badin Sanchez. 2011. 'A Inserção Internacional do Poder Executivo Brasileiro.' Análises e Propostas 40.

Fung, Archon and Erik O Wright. 2003. Deepening democracy: institutional innovations in empowered participatory governance. London: Verso.

Held, David. 2006. Models of Democracy. $3^{\text {rd }}$ edition. Stanford: Stanford University Press.

1999. 'The transformation of political community: rethinking democracy in the context of globalization.' In Ian Shapiro and Cassiano Hacker-Cordón (eds), Democracy's Edges. Cambridge: Cambridge University Press. pp. 84-11.

Hill, Christopher. 2003a. The Changing Politics of Foreign Policy. New York: Palgrave. .2003b. 'What is to be done? Foreign Policy as a site for action.' International Affairs 79 (2):

233-255. 
Hirst, Monica. 2011. 'Prefácio'. In Leticia Pinheiro and Carlos R S Milani (eds), Política externa brasileira a política das práticas e as práticas da política. Rio de Janeiro: FGV Editora. pp. 9-12.

Hirst, Monica Maria Regina Soares Lima and Leticia Pinheiro. 2010. 'A política externa brasileira em tempos de novos horizontes e desafios.' Nueva Sociedad: 22-41.

Holsti, Ole R. 1992. 'Public Opinion and Foreign Policy: Challenges to the Almond-Lippmann Consensus Mershon.' International Studies Quarterly 36(4):439-466.

Ramanzini Júnior, Haroldo and Rogério de Souza Farias. 2015. 'Missão impossível? Mercosul, participação social e política externa no Brasil.' Pensamento Próprio 40: 355-275.

Keohane, Robert. 1969. 'Lilliputian's Dilemmas: Small States in International Politics.' International Organizational 23 (2).

Keohane, Robert and Helen Milner. 1996. Internationalization and Domestic Politics. Cambridge: Cambridge University Press.

Lavalle, Adrian Gurza, Peter Houtzager and Graziela Castello. 2006. 'Representação, Pluralização da Representação e Sociedade Civil'. Lua Nova 57: 49-103.

Leite, Iara C, Bianca Suyama, Laura T Waisbich and Melissa Pomeroy. 2014. Brazil's Engagement in International Development Cooperation: The State of the Debate. Brighton: Institute of Development Studies.

Leite, Iara Costa, Melissa Pomeroy and Bianca Suyama. 2015. 'Brazilian South-South development cooperation: the case of the Ministry of Social Development in Africa.' Journal of International Development 27 (8): 1446-1461.

Lima, Maria Regina Soares. 2000. 'Instituições Democráticas e Política Exterior.' Contexto Internacional 22 (2): 265-303.

Lima, Maria Regina Soares de and Fabiano Santos. 2001. 'O Congresso e a Política de Comércio Exterior.' Lua Nova 52: 121-149.

Lopes, Dawisson Belém. 2013. Política Externa e Democracia no Brasil. São Paulo: UNESP.

Majone, Giandomenico. 1989. Evidence, Argument and Persuasion in the Policy Process. New Haven and London: Yale University Press.

Marcolini, Michele Dolcetti. 2014. 'La participación de las organizaciones de la sociedde civil en la Cooperación Sul-Sur de Brasil: buscando un enfoque integral de participación.' Revista Iberoamericana de Desarrollo 3 (2): 136-147.

Martin, Lisa. 2000. Democratic Commitments: Legislatures and International Cooperation. Princeton: Princeton University Press.

Mesquita, Lucas Ribeiro. 2013. 'Para além do Estado: A Agência no Mercosul Social e Participativo.' Conjuntura Internacional 10(1): 40-50.

2012. 'Sociedade civil e Política Externa Brasileira: os espaços participativos na PEB contemporânea.' OIKOS 11(2): 281-301.

Milani, Carlos. 2011. 'Atores e agendas no campo da política externa brasileira de direitos humanos.' In Letícia Pinheiro and Carlos Milani (eds), Política externa brasileira a política das práticas e as práticas da política. Rio de Janeiro: FGV. pp. 33-70.

2008. 'Discursos y mitos de la participación social en la cooperación internacional para el desarrollo: una mirada a partir de Brasil.' Revista Española de Desarrollo y Cooperación 22: 161-182. 
Milani, Carlos and Letícia Pinheiro. 2013. 'Política Externa Brasileira: Os Desafios de sua Caracterização como Política Pública.' Contexto Internacional 35 (1): 11-41.

Milner, Helen. 2007. Interests, institutions, and information: domestic politics and international relations. Princeton: Princeton University Press.

Morgenthau, Hans. 1978. Politics among Nations. New York: Knopf.

Oliveira, Ivan Tiago Machado and Carlos Milani. 2012. 'Atores não estatais e trade policy - making no Brasil: análise dos interesses e das estratégias da CEB e da REBRIP.' Dados 55(2), 367-401.

Orsino, Susana. 2013. Los procesos de institucionalización de los mecanismos regionales para la equidad de gênero: Reunión Especializada de la Mujer del MERCOSUR (REM). Availabe at: http:// www.mercosurmujeres.org/userfiles/file/files/Orsino.pdf [accessed on January 2016].

PAA Africa. 2015. 'O PAA África e a participação da sociedade civil: visões, limites, e caminhos para o futuro.' PAA Africa. Available at: http://paa-africa.org/pt/wp-content/uploads/sites/6/2015/09/ PAA_Africa_Participacao_Social_REvCGFOME_final.pdf [accessed on September 2015].

Parés, Marc. 2009. Participación y Calidad Democrática: Evaluando las nuevas formas de democracia participativa. Barcelona: Ariel.

Parés, Marc and Carola Castellà. 2009. 'Una propuesta de criterios de calidad democrática para evaluar los procesos participativos.' In Marc Parés (ed), Participación y Calidad Democrática: Evaluando las nuevas formas de democracia participativa. Barcelona: Ariel. pp. 241-266.

Pinheiro, Leticia and Carlos Milani. 2011. Política externa brasileira a política das práticas e as práticas da política. Rio de Janeiro: FGV Editora.

Pires, Roberto C (ed). 2011. Efetividade da Instituições Participativa no Brasil: Estratégias de Avaliação. Brasília: IPEA.

Pogrebinschi, Thamy and David Samuels. 2014. 'The Impact of Participatory Democracy Evidence from Brazil's National Public Policy Conferences.' Comparative Politics: 313-332.

Pomeroy, Melissa. 2009. 'Los significados de la participación.' Msc. Universitat Autónoma de Barcelona.

Putman, Robert. 1988. 'Diplomacy e domestic politics: the logic of two-level games.' International Organization 42 (3): 427-460.

Risse-Kappen, Thomas. 1991. 'Public Opinion, Domestic Structure, and Foreign Policy in Liberal Democracies.' World Politics 43 (4): 479-512.

Sørensen, George. 2006. 'The Transformation of the State.' In Colin Hay, Michael Lister and David Marsh (eds), The State. Theories and Issues. Hampshire: Palgrave Macmillan. pp. 190-208.

Salomón, Mónica and Letícia Pinheiro. 2013. 'Análise de Política Externa Brasileira: trajetória, desafios e possibilidades de um campo de estudo.' Revista Brasileira de Política Internacional 56(1): 40-59.

Sanchez, Michelle Ratton Badin, Elaini Silva, Evorah Cardoso and Priscila Spécie. 2006. 'Política Externa como Política Pública: uma análise pela regulamentação constitucional brasileira (19671988).' Revista de Sociologia Política: 125-143.

Santana, Helton. 2001. 'Grupos de Interesse e a Política Externa para a ALCA.' Contexto Internacional 23 (1): 167-196.

Santoro, Maurício. 2012. 'Democracia e Política Externa no Brasil'. Revista Estudos Políticos 4 (01): 95-105 
Santos, Tacilla da Costa eSá Siqueira. 2013. Entre o Norte e o Sul: um estudo sobre o papel das organizações da sociedade civil brasileira na cooperação internacional para o desenvolvimento. Phd. Universidade Federal da Bahia, Escola de Administração.

Schmitz, Guilherme de Oliveira. 2014. 'A Sociedade civil brasileira e a cooperação sul-sul para o desenvolvimento: estudo de caso do Viva Rio no Haiti.' Boletim de Economia e Política Internacional 16: 75-90.

Shankland, Alex and Euclides Gonçalves. 2016. Imagining Agricultural Development in SouthSouth Cooperation: The Contestation and Transformation of ProSAVANA, World Development, Available at: http://dx.doi.org/10.1016/j.worlddev.2016.01.002 [accessed on February 2016].

Silva, Elaini Cristina Gonzaga da, Priscila Spécie and Denise Vitale. 2010. Atual arranjo da Política Externa Brasileira. Discussion Paper, Brasília: IPEA.

Soares, Clemente de Lima Baena. 2005. O processo legislativo e a aprovação de acordos internacionais assinados pelo Brasil. Phd. Instituto Rio Branco.

Steil, Carlos Alberto and Isabel Carvalho. 2001. 'ONGs no Brasil: elementos para uma narrativa política.' Humanas 24 (2): 36-55.

Suyama, Bianca and Melissa Pomeroy. 2014. Supporting 'Autonomy and Resistance' The Brazil-Mozambique-South Africa native seed bank project. Sussex: Institute of Development Studies.

Tarrow, Sidney. 2005. The New Transnational Activism. Cambridge: Cambridge University Press.

Veiga, Pedro de Motta. 2007. 'Trade policy-making in Brazil: Changing patterns in state-civil society relationship.' In Mark Halle and Robert Wolfe (eds), Process matters: Sustainable Development and Domestic Trade Transparency. Winnipeg: IISD. pp. 143-183.

Villa, Rafael Duarte and Ana Paula Baltasar Tostes. 2006. 'Democracia cosmopolita versus política internacional.' Lua Nova 66: 69-107.

\section{About the Author}

Melissa Pomeroy holds a PhD in Political Science from the Institute of Government and Public Policy at the Autonomous University of Barcelona, an MSc in Political Science and a specialisation in Participation and Sustainable Development from the same university. In 2011, she collaborated with the creation of Articulação SUL, a research and policy centre focused on South-South co-operation, where she is currently the programme co-ordinator and editor of the Brazilian and the South Observatory. Her main areas of interest are social movements and citizen participation, the analysis and evaluation of public policies, international development co-operation, and foreign policy. Previous working experience includes São Paulo's Participatory Budget, the International Observatory of Participatory Democracy and the Institute of Government and Public Policy, both based in Barcelona.

Received on 28 October 2015 and approved for publication on 3 March 2016.

\section{(cc) BY-NC} https://creativecommons.org/licenses/by-nc/4.0/ 
